\title{
Learning from My Dad: Donald A.B. Lindberg M.D.
}

\author{
Donald A.B. LINDBERGH, IT Cybersecurity Specialist, Indianapolis, IN. U.S.A. ${ }^{1}$
}

Keywords. Donald A.B. Lindberg M.D., Lindberg family history

\section{Farm}

I read an article by Betsy Humphreys mentioning a remembrance by Diane McKenzie that my dad "relished his role as the crowing rooster" during a 'Comin' Round the Mountain' game at a 1986 Medical Library Association chapter meeting in Jackson Hole, WY. "He did it with gusto, McKenzie recalled. He earned my eternal support with his willingness to be silly with the rest of us" [1].

My dad (Donald A.B. Lindberg M.D.) really did a good cow moo as well.

However, his best 'pre-verbal' exclamation was when Jon, Chris, and I were very young and on horseback with him at our farm in Missouri, a fantastic 130-acre location.

My brothers and I prepared by getting well seated in the saddle and a firm hold on the reins, egging him on and knowing what was to come. Then, my dad would let out a blood curding scream like a Comanche, and the horses would take off at full tilt, and we raced across the fields.

He kept a shearling-lined leather rifle scabbard on his saddle at all times. If we encountered hunters on the property, he would approach them and make sure they saw the rifle. Then, dad demanded to know what the hell they were doing on his land. It was like something out of 'Gunsmoke,' a TV show we all loved.

We had a cabin on the farm, and we helped dad build bunk beds for each of us. The cabin had a heater named 'Shingebiss' after the Ojibwa Native American story we begged him to read to us repeatedly [2].

\section{Reading}

When my brothers and I were very young, dad read to us nightly regularly. We had a separate, dedicated library, so the available options were many. These included traditional stories from Greek mythology; Daedalus and Icarus was a popular, recurring choice [3]. My personal favorite came from a Japanese mythology collection, a tale of the Rokurobuki, guaranteed to scare and delight every time [4].

I'm still trying to reconnect with that book from my dad's remaining vast collection.

\footnotetext{
${ }^{1}$ Corresponding author: don@donlindbergh.com
} 


\section{New York City}

Dad took me to New York when I was 11 or 12. I was super excited.

After arriving in a rental car leaving LaGuardia Airport, a cab behind us honks for us to get a move on. Dad instantly gets out of the car and approaches the taxi behind us, causing the cab driver to react in terror and quickly lock all his doors. Dad pounds on the driver side window - BOOM BOOM BOOM.... 'DON'T HONK YOUR HORN AT ME.' Then, he calmly gets back in our car, puts it into gear, and eventually pulls forward. When he damn well pleases....

Once in the city, we often found ourselves in cabs. These were thrilling and somewhat terrifying experiences for me as I could not believe how fast they drove and how narrowly they seemed to escape collisions. After giving one driver a tip, the cabbie took dad for a tourist and asked if he would tip 20 percent. Dad, who grew up in Brooklyn, proceeded to lay into the cab driver about how New York's cabbies were the worst in the world and whether he would like to be reported to get his medallion removed for reckless driving. Dad suggested he would be happy to take back the tip, being barely deserved.

Waiting at the hotel desk once, with nobody paying attention or coming to attend, dad pounded on the desk. BOOM BOOM BOOM. HEY! LOOK ALIVE! A stunned staff immediately hopped to attention.

Taking me to Chock Full O' Nuts in the morning to get breakfast, the restaurant was at capacity and crazy busy and loud. Sitting at the counter, the drill was to be ready when the counter clerk finally came by to take your order. I hesitated, so dad ordered, and the clerk said she would return for mine. It soon became clear you only got one shot, and she was not planning a comeback. This time dad did not take charge but counseled $I$ needed to get her attention.

I flagged her down. HEY! I'm READY TO ORDER!

\section{Work}

My brothers and I were rounded up for chores around the house including cutting down trees for firewood. When we asked about allowances, dad came up with a pay scale per job. Twenty-five cents to sweep out the garage and for other chores. However, he made it clear there would not be a payout every week without a job being done.

\section{Some of Dad's Enduring Messages}

Don't take (expletive deleted) from anybody, don't wait around for somebody to pay attention to you, don't wait around for somebody to ask you to do something to help.

Later in life, I lamented about losing a job and pondered how to explain it in an interview. In a letter, dad said I should clarify that I had been a dedicated, loyal employee who tirelessly supported a broken old computer system for years, which was a perfect encapsulation.

Reading his letter, a friend of mine remarked: 'you've got a good dad.'

I agreed. 


\section{References}

[1] http://jmla.mlanet.org/ojs/jmla/article/view/878/1083. Retrieved March 18, 2021.

[2] https://en.wikipedia.org/wiki/Rokurokubi_(folktale). Retrieved March 18, 2021.

[3] https://greekreporter.com/2018/04/17/the-tragic-story-of-the-fall-of-icarus/ https://en.wikipedia.org/wiki/Daedalus. Retrieved March 18, 2021.

[4] https://en.wikipedia.org/wiki/Shingebiss. Retrieved March 17, 2021. 